\title{
HEPATITIS B VACCINATION COVERAGE OF HEALTHCARE PROFESSIONALS IN GREECE
}

\author{
ANNA PSARROU ${ }^{1}$, IOANNIS MOISOGLOU ${ }^{3}$, EVANGELIA MEIMETI $^{2}$, GEORGE DOUNIAS $^{4}$, \\ ANASTASIA KIKEMENI ${ }^{4}$, SPYROS SIAKAVELLAS ${ }^{5}$, GRIGORIOS LEON ${ }^{6}$, MARTHA-SPYRIDOULA \\ KATSAROU $^{2}$, MARIA LAGIOU ${ }^{2}$, BORIS N. IZOTOV ${ }^{7}$, NIKOLAOS DRAKOULIS ${ }^{2 *}$ \\ ${ }^{1}$ First Department of Internal Medicine, 401 General Military Hospital of Athens, Greece \\ ${ }^{2}$ Research Group of Clinical Pharmacology and Pharmacogenomics, Faculty of Pharmacy, School of Health Sciences, National \\ and Kapodistrian University of Athens, Greece \\ ${ }^{3}$ Quality Assurance and Continuing Education Unit, General Hospital of Lamia, Greece \\ ${ }^{4}$ Occupational \& Environmental Health, National School of Public Health in Athens, Greece \\ ${ }^{5}$ Department of Gastroenterology, Laiko General Hospital, Medical School, School of Health Sciences, National and \\ Kapodistrian University of Athens, Greece \\ ${ }^{6}$ Medicolegal office, Alexandras Ave. 120, Athens, Greece \\ ${ }^{7}$ Department of Analytical Toxicology, Pharmaceutical Chemistry and Pharmacognosy, Sechenov University, 119991, Moscow, \\ Russia
}

*corresponding author: drakoulis@pharm.uoa.gr

Manuscript received: November 2017

\begin{abstract}
It has been reported that hepatitis B virus (HBV) is 10 times more infectious than hepatitis C virus (HCV) and 100 times more infectious than human immunodeficiency virus (HIV). Although there are two approved and very effective antivirals that quickly reduce the viral load (HBV DNA) and the risk of liver damage, vaccination prevention still represents the ideal intervention to reduce the spread of the disease and to protect public health. A literature review of the studies published in English on hepatitis B vaccination coverage of healthcare professionals in Greece during the 2006 - 2016 period was conducted. The literature review highlighted 12 studies. Healthcare professionals' vaccine rate ranged between $55 \%$ and $88 \%$. Doctors had the higher vaccination rate among healthcare professionals and registered nurses compared to nurses' aides $(\mathrm{p}<0.05)$. Higher educational level, knowledge of hepatitis B and a positive attitude toward vaccines $(\mathrm{p}<0.05)$ revealed as the variables that affect positively healthcare professionals to be vaccinated. Mandatory vaccination of professionals within a health policy with regard to vaccination, as well as the implementation of information programs for them, are two important interventions that may increase vaccination coverage rates.
\end{abstract}

\section{Rezumat}

Studiile au arătat că virusul hepatitei B (HBV) este de 10 ori mai contagios decât virusul hepatitei C (HCV) şi de 100 de ori mai contagios decât virusul imunodeficienței umane (HIV). Cu toate că există aprobate două medicamente antivirale foarte eficiente care pot reduce repede încărcătura virală (HBV DNA), precum și riscul afectării hepatice, prevenția prin vaccinare reprezintă intervenția ideală pentru a reduce răspândirea bolii şi pentru a proteja sănătatea celorlalți. În prezentul studiu s-a realizat o analiză a tuturor studiilor publicate în limba engleză despre vaccinarea împotriva hepatitei B în rândul profesioniştilor din domeniul sănătății din Grecia între anii 2006 și 2016. S-au identificat 12 astfel de publicații științifice. Rata de vaccinare a profesioniștilor din domeniul sănătății este între 55 și $88 \%$. Cea mai mare rată de vaccinare se întâlnește în rândul medicilor, urmați de asistente și infirmiere $(\mathrm{p}<0.05)$. Factorii care influențează pozitiv vaccinarea sunt nivelul de educație superior, cunoștințele legate de hepatita B și atitudinea pozitivă legată de vaccinare. Implementarea unei politici de sănătate publică cu privire la vaccinare care să oblige profesioniștii din sănătate să se vaccineze, precum și implementarea unor programe de informare a profesioniștilor cu privire la vaccinare sunt două dintre cele mai importante intervenții care pot crește rata de vaccinare în rândul acestora.

Keywords: HBV, healthcare professional, hepatitis B, vaccination

\section{Introduction}

The hepatitis B virus is one of the most infectious pathogenic virus that can survive up to 7 days outside of the human body and lead to infection. It has been reported that hepatitis $\mathrm{B}$ virus $(\mathrm{HBV})$ is 10 times more infectious than hepatitis $\mathrm{C}$ virus $(\mathrm{HCV})$ and 100 times more infectious than human immuno- deficiency virus (HIV) [7]. HBV is a major public health problem, according to the WHO (World Health Organization) [32]. In this regard, 257 million people were suffering from hepatitis B in 2015 and almost 900 thousand people died mainly due to HBV infection complications, including cirrhosis and liver cancer in the same year [32]. 
FARMACIA, 2018, Vol. 66, 4

In $2015,9 \%$ of the infected persons were aware of their diagnosis and only $8 \%$ of them received any treatment. Among the diagnosed, the proportion of eligibility for treatment was unclear. Although there are two approved and very effective antivirals entecavir and tenofovir - that quickly reduce the viral load (HBV DNA) and risk of liver damage, vaccination prevention still represents the ideal intervention to reduce the spread of the disease and protect public health. Since 1982, the vaccine release year, WHO estimated that 1 billion vaccines have been administered worldwide. Global vaccination coverage with all three doses of the vaccine has reached $84 \%$ of the world's population, but the European, Eastern Mediterranean and African regions faced coverage gaps [32].

Internationally, healthcare professionals are among the high-risk groups for HBV infection, with the prevalence varying between healthcare professionals of different specialties and between countries $[1,3$, $4,19]$.

Disease transmission occurs usually transdermally and through the mucosa following contact with infected blood or other biological fluids of a patient. According to an earlier WHO report [33], two million healthcare professionals suffer injury from a hepatitis $B$ virus-infected item every year. It is estimated that about 66,000 new cases of HBV infection are due to the above injuries [26]. Contamination with such a disease not only affects the wellbeing of healthcare professionals, but also poses a major risk to their patients, colleagues and people in their environment. The financial burden of the disease is also high, as the costs include treating the disease, complications and loss of productivity due to absenteeism [13].

The purpose of this study was to investigate the hepatitis $\mathrm{B}$ vaccination coverage of healthcare professionals in Greece.

\section{Materials and Methods}

A literature review of the studies published in English on hepatitis $\mathrm{B}$ vaccination coverage of healthcare professionals in Greece during the 2006-2016 period was conducted. The review included studies carried out on healthcare professionals working in primary and secondary structures, such as hospitals, private clinics and health centres. The term "healthcare professionals" means all professionals providing direct or indirect care to patients as well as the administrative and technical staff of the above structures. Vaccination coverage studies of medical students have been included in the analysis, because they come in direct contact with patients during their medical training. Furthermore, bibliographic references to the articles resulting from the search were evaluated. The search was performed using PubMed and
CINAHL databases. Key words used were: HBV, Healthcare professional, Hepatitis B, Students, Vaccine.

\section{Results and Discussion}

The literature analysis highlighted 12 studies, which were carried out and published between 2006 and 2016. (Table I).

Five studies concerned public healthcare professionals and health centres $[12,15-17,27]$. The study by Saridi et al concerned 338 healthcare professionals from a regional hospital, who had been fully vaccinated for hepatitis $\mathrm{B}$ in a percentage of $58.6 \%$, which means that 198 participants received at least one dose [27]. However, of the 198 participants, only 159 were fully vaccinated ( 3 doses), accounting for $47 \%$ of the study population. Among $\mathrm{HCWs}$, doctors, technicians and nurses are the groups with the highest percentage of vaccination coverage, with rates of $77.3 \%, 68 \%$ and 60.4 , respectively. The analysis revealed statistically significant relationships between vaccination and professional capacity $(\mathrm{p}<0.001)$, with doctors having the highest percentage of vaccination coverage, vaccination and work $(\mathrm{p}<0.001)$, with those working at Special Care Units having the highest percentage of vaccination coverage as well as vaccination and educational level $(\mathrm{p}<0.001)$. University degree holders have higher rates of vaccination.

The study of Maltezou et al, conducted in 4 tertiary hospitals, with a total of $505 \mathrm{HCWs}$ participated in the study [16]. Although most HCWs (90.3\%) were aware of the recommendations for vaccination against hepatitis B from the Ministry of Health, results showed that $56.5 \%$ of healthcare professionals were vaccinated for hepatitis B. Analysis showed that physicians had the lower rate of correct answers regarding recommended vaccines compared to nurses and other professional groups (14.8\% compared to $26.1 \%$ and $19.7 \%$ respectively, $\mathrm{p}$-value $=0.024)$. Also, the younger age groups had higher rates of vaccination coverage $(p<0.001)$, with physicians having higher rates of accepting compulsory vaccination, compared to nursing staff and other professionals $(\mathrm{p}<0.028)$.

A further study involving 2,055 healthcare professionals in primary care facilities was conducted by Maltezou et al [17]. According to their responses, 55.7\% of participants were fully vaccinated for hepatitis B. Regarding mandatory vaccination, the vast majority of the participants $(87.3 \%)$ indicated that hepatitis B vaccination should be mandatory. Among HCWs, the doctors included in this study had higher rates of acceptance of a compulsory vaccination policy than other healthcare professionals $(\mathrm{p}<0.001)$. Furthermore, Maltezou et al investigated the hepatitis B vaccination percentage of healthcare professionals in paediatric departments of 3 large hospitals [15]. A total of 212 of the 306 participants $(69.2 \%)$ declared full vaccination for hepatitis B. The study by Karaivazoglou et al 
FARMACIA, 2018, Vol. 66, 4

took place in 2 hospitals with the participation of 183 healthcare professionals [12]. The vaccination coverage for hepatitis B was $70.9 \%$. The multivariate statistical analysis showed that the occupational category (physicians) $(\mathrm{HR}=0.15,95 \% \mathrm{CI}=0.06$ $0.377, \mathrm{p}<0.001)$, education level (academic) $(\mathrm{HR}=$ $0.267,95 \% \mathrm{CI}=0.115-0.618, \mathrm{p}=0.002)$, and knowledge of hepatitis $\mathrm{B}(\mathrm{HR}=1.097,95 \% \mathrm{CI}=$
$1.0-1.202, \mathrm{p}=0.04)$ was statistically associated with the acceptance of the vaccines (Table I). Further, the study revealed that negligence $(25.0 \%)$, lack of time $(23.1 \%)$, perceptions of no risk $(19.2 \%)$, fear of side effects $(19.2 \%)$ and doubts about vaccine efficacy $(13.5 \%)$ consist of the major reasons for participants not being vaccinated.

\begin{tabular}{|c|c|c|c|c|c|}
\hline \multicolumn{6}{|c|}{ Vaccination coverage of health professionals in Greece (2006 - 2016) } \\
\hline $\begin{array}{l}\text { Year of } \\
\text { study }\end{array}$ & Journal & \begin{tabular}{|c|}
$\begin{array}{c}\text { Number of } \\
\text { participants }\end{array}$ \\
\end{tabular} & $\begin{array}{c}\text { Healthcare } \\
\text { professionals enrolled }\end{array}$ & $\begin{array}{l}\text { Vaccinated } \\
(\%)\end{array}$ & Antibodies \\
\hline 2007 & $\begin{array}{l}\text { Infection Control and } \\
\text { Hospital Epidemiology }\end{array}$ & 187 & $\begin{array}{c}\text { Medical and nursing } \\
\text { students }\end{array}$ & 80.7 & $84.4 \% \geq 10 \mathrm{IU} / \mathrm{L}$ \\
\hline $2006-2008$ & $\begin{array}{c}\text { Journal of Vaccines\& } \\
\text { Vaccination }\end{array}$ & 338 & $\begin{array}{c}\text { HCWs of a public } \\
\text { general hospital }\end{array}$ & 58.6 & $\begin{array}{c}65.4 \%<100 \mathrm{mIU} / \mathrm{mL} \\
33.7 \% \text { in } 100-1000 \mathrm{mIU} / \mathrm{mL} \\
0.9 \%>1000 \mathrm{mIU} / \mathrm{mL}\end{array}$ \\
\hline 2007 & $\begin{array}{l}\text { Review of Clinical } \\
\text { Pharmacology and } \\
\text { Pharmacokinetics, } \\
\text { International Edition }\end{array}$ & 150 & $\begin{array}{l}\text { Nurses and Midwifes of } \\
\text { one university hospital }\end{array}$ & 77.3 & Not recorded \\
\hline $2007-2009$ & Journal of Renal Care & 216 & $\begin{array}{l}\text { Haemodialysis nurses of } \\
20 \text { dialysis centres }\end{array}$ & 80.6 & $\begin{array}{c}30.1 \% \text { in } 100-1000 \mathrm{mIU} / \mathrm{mL} \\
34.7 \%>1000 \mathrm{mIU} / \mathrm{mL}\end{array}$ \\
\hline 2008 & $\begin{array}{l}\text { Nursing and Health } \\
\text { Sciences }\end{array}$ & 418 & Nursing students & 65.7 & Not recorded \\
\hline 2009 & $\begin{array}{c}\text { Balkan Military Medical } \\
\text { Review }\end{array}$ & 245 & $\begin{array}{l}\text { Nurses in } 7 \text { military } \\
\text { hospitals }\end{array}$ & 75.5 & Not recorded \\
\hline 2010 & $\begin{array}{l}\text { American Journal of } \\
\text { Infection Control }\end{array}$ & 2,055 & $\begin{array}{l}\text { HCWs of } 185 \text { primary } \\
\text { healthcare centres }\end{array}$ & 55.7 & Not recorded \\
\hline $2010-2011$ & Journal of Infection & 505 & $\begin{array}{c}\text { HCWs of } 4 \text { tertiary } \\
\text { hospitals }\end{array}$ & 56.5 & Not recorded \\
\hline $2010-2011$ & $\begin{array}{c}\text { The Pediatric Infectious } \\
\text { Disease Journal }\end{array}$ & 306 & $\begin{array}{c}\text { HCWs of the paediatrics } \\
\text { units of } 3 \text { public } \\
\text { hospitals }\end{array}$ & 69.2 & Not recorded \\
\hline $2012-2013$ & Vaccine & 165 & $\begin{array}{l}\text { Healthcare students } \\
\text { (Nursing and Medical } \\
\text { Laboratories Faculty) }\end{array}$ & 70 & Not recorded \\
\hline 2013 & $\begin{array}{c}\text { Archives of } \\
\text { Environmental \& } \\
\text { Occupational Health }\end{array}$ & 183 & $\begin{array}{l}\text { HCWs of } 2 \text { public } \\
\text { hospitals }\end{array}$ & 70.9 & Not recorded \\
\hline $2013-2014$ & $\begin{array}{c}\begin{array}{c}\text { International Journal of } \\
\text { Environmental Research } \\
\text { and Public Health) }\end{array} \\
\end{array}$ & 1,717 & $\begin{array}{c}\text { Healthcare students } \\
\text { (medicine, nursing and } \\
\text { paramedical) }\end{array}$ & 83 & Not recorded \\
\hline
\end{tabular}

The nursing staff was the studied population of 3 studies, with regard to vaccination coverage for hepatitis B $[21,29,30]$. The participants $(n=245)$ in the Tsoulas and Apostolopoulou study, which took place in 7 military hospitals, reported $75.5 \%$ of them vaccinated for hepatitis B [30]. The multivariate analysis showed that registered nurses compared to the nurses' aides $(\mathrm{OR}=2.13,95 \% \mathrm{CI}=1.1-4.3$, $\mathrm{p}=0.02)$ and nursing staff aged less than 34 years had a higher probability of vaccination $(\mathrm{OR}=9.1$, $95 \% \mathrm{CI}=1.45-58.47, \mathrm{p}=0.01)$. The individuals who considered the vaccine safe $(\mathrm{OR}=3.58,95 \%$ $\mathrm{CI}=1.77-7.24, \mathrm{p}=0.001)$ and effective $\mathrm{OR}=8.8$, $95 \% \mathrm{CI}=2.26-34.59, \mathrm{p}=0.001)$ was more likely to be vaccinated. The study by Topka et al concerned the incidence of hepatitis B in the nursing $(n=216)$ staff of 20 haemodialysis units [29]. The percentage of participants who said they had been vaccinated was of $80.6 \%$, but only $69 \%$ had received 3 or more doses of the vaccine [29].

The vaccination coverage of the students of health schools was the subject of 4 studies [11, 22-24]. In the studies of Noula et al, Pavlopoulou et al and Karageorgou et al the percentage of vaccination coverage of the students was $65.7 \%, 84.4 \%$ and $70 \%$, respectively. In the above studies, no statistical analysis was carried out to correlate the rates of vaccination coverage with demographic or other data of the participants. According to students' answers [22], negligence was the major vaccine-uptake barrier. In the study of Papagiannis et al participated 1,717 students from the 6 important universities of medicine, 
FARMACIA, 2018, Vol. 66, 4

nursing and paramedical professions in Greece [23]. The vaccination coverage rate of these students, who were in the $3^{\text {rd }}$ and $4^{\text {th }}$ year of their studies, was $83 \%$. While the majority of participants (96\%) agreed that vaccines are important for the protection both of public health and of healthcare workers, however, inertia $(60 \%)$ and fear $(30 \%)$ over HBV vaccine safety were the two major reasons of no vaccination. The results of multivariate analysis showed that medical students were more likely to report vaccination against HBV compared to other students $(\mathrm{OR}=1.71 ; 95 \%$ CI: $1.25-2.34, p=0.021)$. Those who considered vaccines to be important for the protection of public health had a higher probability of vaccination than those who had the opposite view (OR $=2.03 ; 95 \%$ CI: $1.10-3.72, p<0.001)$ and students who reported a positive opinion towards vaccination, in general, were more likely to report vaccination against HBV $(\mathrm{OR}=1.53,95 \%$ CI: 1.00 - 2.35) (Table I).

Vaccines are among the most important discoveries in the pharmaceutical and medical field, through prevention providing protection for public healthcare. Healthcare professionals are at a high risk of hepatitis B infection due to their contact with the blood and biological fluids [20], and can be protected by full vaccination. Although the safety and efficacy of hepatitis B vaccine are proven, however, vaccination coverage rates of healthcare professionals in Greece are relatively low. According to the bibliographic review, coverage rates of healthcare professionals in Greece ranged from $55.7 \%$ to $70.9 \%$ for the nursing staff from $75.5 \%$ to $80.6 \%$ and for health school students from $65.7 \%$ to $83 \%$. The results of vaccine coverage surveys at international level showed a percentage of coverage of healthcare professionals of $82.4 \%$ in a Brazilian university hospital [5], of $70.1 \%$ for 51 Italian hospitals [8]. As for US healthcare professionals, the rate of vaccination with 3 or more doses of hepatitis $B$ vaccine was $63.4 \%$, while the proportion of those having direct contact with patients was $74.0 \%$ [2]. The rates of the data presenting for Greece are very close to those of other international reports. In Greece, hepatitis B vaccination for healthcare professionals is not mandatory to carry out their work, but has been included in the national vaccination program and therefore its cost is fully covered by the insurance funds and can be made in public hospitals, free of charge, to uninsured persons. The implementation of a health policy for the healthcare professionals' safety, which would be based on the statutory introduction of compulsory vaccination of hepatitis $B$ healthcare professionals, could be an effective intervention to increase the vaccination coverage of healthcare professionals. Several European countries have legislated compulsory vaccination of healthcare professionals for their recruitment to health facilities, while others have introduced compulsory vaccination for healthcare professionals who are involved in clinical practice and come into contact with biological fluids [14]. Studies in different countries, which have legislated compulsory inoculation for recruitment and specific occupational groups respectively, have shown very high rates of vaccination coverage, reaching 100\% of the participants $[9,18,28]$.

Healthcare professionals' belief and attitude towards vaccine safety seems to play an important role in the decision to vaccinate, which, according to the results of the studies presented, increased the chances of vaccination when they have a positive attitude for vaccines. For several years now, vaccines have been targeting anti-vaccination movements that challenge their safety by using misinformation techniques with non-scientifically documented information, resulting in a severe disruption of vaccination programs for the general population, posing many risks to public health $[6,25]$.

The fields of activity of anti-vaccination are most often the internet and social media, where there is easy and rapid access for the population. As a consequence, for example, measles epidemics were recently reported in countries from Europe, the Balkans and Greece. The effect of anti-vaccination may trigger a negative impact also on some healthcare professionals. Reliable information and scientific data should be provided to healthcare professionals periodically and therefore could positively influence their attitudes towards vaccines, while increasing their availability for vaccination [10].

\section{Conclusions}

Vaccination coverage rates for healthcare professionals in Greece are at about the same levels as in other countries. The high risk of hepatitis B infection for healthcare professionals, particularly those having a direct contact with patients and biological fluids, and the significant impact of the illness, make vaccination of healthcare professionals imperative not only as a personal precaution, but also as a measure to protect public healthcare.

Undoubtedly, compulsory vaccination of professionals within a health policy with regard to vaccination, as well as the implementation of information programs, are two important interventions that may increase vaccination coverage rates.

\section{Acknowledgement}

We would like to thank Mrs. Ioulia D. Soulioti for her help regarding the literature search.

\section{References}

1. Bosques-Padilla FJ, Vazquez-Elizondo G, VillasenorTodd A, Garza-González E, Gonzalez-Gonzalez JA, Maldonado-Garza HJ, Hepatitis C virus infection in 
health care settings: medical and ethical implications. Ann Hepatol., 2010; 9: 132-140.

2. Byrd KK, Lu PJ, Murphy TV, Hepatitis B vaccination coverage among health-care personnel in the United States. Public Health Rep., 2013; 128(6): 498-509.

3. Cerbin-Koczorowska M, Waszyk-Nowaczyk M, Odor K, Michalak M, Piotrowska S, Matschay A, Simon M, Majchrzycki M, Pharmaceutical care as a chance of improving health care in areas with an average level of urbanization. Farmacia, 2017; 65(1): 159-166.

4. Ciorlia LAS, Zanetta DMT, Hepatitis B in health workers: prevalence, vaccination and relation to occupational factors. Braz J Infect Dis., 2005; 9(5): 384-389.

5. Dinelli MI, Moreira TD, Paulino ER, da Rocha MC, Graciani FB, de Moraes-Pinto MI, Immune status and risk perception of acquisition of vaccine preventable diseases among health care workers. Am J Infect Control., 2009; 37(10): 858-860.

6. Dubé E, Vivion M, MacDonald NE, Vaccine hesitancy, vaccine refusal and the anti-vaccine movement: influence, impact and implications. Exp Rev Vaccines, 2015; 14(1): 99-117.

7. Feldman M, Friedman LS, Brandt LJ, Sleisenger and Fordtran's Gastrointestinal and Liver Disease - 2 Volume Set: Pathophysiology, Diagnosis, Management, $9^{\text {th }}$ Edition. 2010. Saunders: Philadelphia.

8. Fortunato F, Tafuri S, Cozza V, Martinelli D, Prato $\mathrm{R}$, Low vaccination coverage among Italian health workers in 2013. Hum Vaccin Immunother., 2015; 11(1): 133-139.

9. Guthmann JP, Fonteneau L, Ciotti C, Bouvet E, Pellissier G, Lévy-Bruhl D, Abiteboul D, Vaccination coverage of health care personnel working in health care facilities in France: results of a national survey, 2009. Vaccine, 2012; 30(31): 4648-54.

10. Herzog R, Álvarez-Pasquin MJ, Díaz C, Del Barrio JL, Estrada JM, Are health workers' intentions to vaccinate related to their knowledge, beliefs and attitudes? A systematic review. BMC Public Health., 2013; 13: 1-17.

11. Karageorgou K, Katerelos P, Efstathiou A, Theodoridou $\mathrm{M}$, Vaccination coverage and susceptibility against vaccine-preventable diseases of health students in Athens, Greece. Vaccine, 2014; 32(39): 5083-5086.

12. Karaivazoglou K, Triantos C, Lagadinou M, Bikas C, Michailidou M, Kalafateli M, Thomopoulos K, Assimakopoulos K, Nikolopoulou V, Jelastopulu E, Labropoulou-Karatza C, Acceptance of hepatitis B vaccination among health care workers in Western Greece. Arch Environ Occup Health., 2014; 69(2): 107-111.

13. Lavanchy D, Worldwide epidemiology of $\mathrm{HBV}$ infection, disease burden, and vaccine prevention. $J$ Clin Virol., 2005; 34(Supp11): S1-S3.

14. Maltezou HC, Wicker S, Borg M, Heininger U, Puro V, Theodoridou M, Poland GA, Vaccination policies for health-care workers in acute health-care facilities in Europe. Vaccine, 2011; 29(51): 9557-9562.

15. Maltezou HC, Lourida A, Katragkou A, Grivea IN, Katerelos P, Wicker S, Syrogiannopoulos GA, Roilides E, Theodoridou M, Attitudes regarding occupational vaccines and vaccination coverage against vaccinepreventable diseases among health workers working in pediatric departments in Greece. Pediatr Infect Dis J., 2012; 31(6): 623-625.

16. Maltezou HC, Gargalianos P, Nikolaidis P, Katerelos P, Tedoma N, Maltezos E, Lazanas M, Attitudes towards mandatory vaccination and vaccination coverage against vaccine-preventable diseases among health-care workers in tertiary-care hospitals. $J$ Infect., 2012; 64: 319-324.

17. Maltezou HC, Katerelos P, Poufta S, Pavli A, Maragos A, Theodoridou M, Attitudes toward mandatory occupational vaccinations and vaccination coverage against vaccine-preventable diseases of health care workers in primary health care centers. Am J Infec Control., 2013; 41(1): 66-70.

18. Mir O, Adam J, Gaillard R, Gregory T, Veyrie N, Yordanov Y, Berveiller P, Chousterman B, Loulergue $\mathrm{P}$, Vaccination coverage among medical residents in Paris, France. Clin Microbiol Infect., 2012; 18(5): E137-139.

19. Nagao Y, Matsuoka H, HBV and HCV infections in Japanese dental care workers. Int J Mol Med., 2008; 21: 791-799.

20. Nienhaus A, Kesavachandran C, Wendeler D, Haamann F, Dulon M, Infectious diseases in health workers - an analysis of the standardised data set of a German compensation board. J Occupl Med Toxicol., 2012; 7(1): 1-7.

21. Noula M, Mastrogiannis D, Mantzorou M, Chouridou Ch, Deltsidou A, Vaccination coverage of nursing staff against Hepatitis B and information source about Hepatitis prevention. Rev Clin Pharmacology and Pharmacokinetics, Int Ed., 2007; 21: 271-277.

22. Noula M, Raftopoulos V, Gesouli E, Tsaprounis T, Deltsidou A, Greek nursing students' immunization coverage: Data from central continental Greece. Nurs Health Sci., 2008; 10(3): 169-174.

23. Papagiannis D, Tsimtsiou Z, Chatzichristodoulou I, Adamopoulou M, Kallistratos I, Pournaras S, Arvanitidou $\mathrm{M}$, Hepatitis B virus vaccination coverage in medical, nursing, and paramedical students: A cross-sectional, multi-centered study in Greece. Int $J$ Environ Res Public Health., 2016; 13(3): 1-9.

24. Pavlopoulou D, Daikos GL, Tzivaras A, Bozas E, Kosmidis C, Tsoumakas C, Theodoridou M, Medical and nursing students with suboptimal protective immunity against vaccine-preventable diseases. Infect Control Hosp Epidemiol., 2009; 30(10): 1006-1011.

25. Poland GA, Jacobson RM, Understanding those who do not understand: a brief review of the antivaccine movement. Vaccine, 2001; 19: 2440-2445.

26. Pruss-Ustun A, Rapiti E, Hutin Y, Estimation of the global burden of disease attributable to contaminated sharps injuries among health-care workers. Am J Ind Med., 2005; 48(6): 482-490.

27. Saridi M, Toska A, Souliotis K, Orfanos N, Sietou M, Stamatiou K, Farmaki K, Vaccination coverage among health care workers in a Greek hospital. $J$ Vaccines Vaccin., 2011; 2: 1-8.

28. Streinu-Cercel A, Sandulescu O, Manolache D, Stoica MA, Preoțescu LL, Streinu-Cercel A, Drug-drug interaction (DDI) tools - useful versus mandatory in the management of difficult to treat patients with chronic HCV infection. Farmacia, 2017; 65(1): 136-141. 
FARMACIA, 2018, Vol. 66, 4

29. Topka D, Theodosopoulos L, Elefsiniotis I, Saroglou $\mathrm{G}$, Prevalence of hepatitis B in haemodialysis nursing staff in Athens. Journal of Renal Care, 2012; 38(2): 76-81.

30. Tsoulas D, Apostolopoulou E. Hepatitis B vaccination coverage levels among Health Care Workers in Greek Military Hospitals. Balkan Military Medical Review.2009;12: 133-142.
31. World Health Organization (2015). Hepatitis B. Fact sheet. www.who.int.

32. World Health Organization (2017). Hepatitis B. Fact sheet. www.apps.who.int.

33. World Health Organization (2002). The World Health Report 2002: Reducing risks, Promoting Healthy Life. www.who.int. 